\title{
Assessment of Lipid Compounds and Phosphorus in Mangrove Sediments of Santa Catarina Island, SC, Brazil
}

\author{
Luciana Mater, Marcelo R. Alexandre, Fabrício A. Hansel and Luiz A. S. Madureira* \\ Departamento de Química, Universidade Federal de Santa Catarina, 88040-900 Florianópolis - SC, Brazil
}

\begin{abstract}
Lipídios provenientes de sete estações sedimentares foram usados para avaliar fontes de matéria orgânica em dois manguezais localizados na Ilha de Santa Catarina, SC. O manguezal de Ratones encontra-se em uma área de preservação permanente, com pouca influência humana. Em contraste, o manguezal do Itacorubi tem sofrido sérios impactos por atividades antrópicas devido à sua proximidade da cidade de Florianópolis. Os maiores níveis de carbono orgânico $\left(2,13 \mathrm{mmol} \mathrm{g}^{-1}\right) \mathrm{e}$ fósforo total $\left(14,9 \mu \mathrm{mol} \mathrm{g}^{-1}\right)$ foram encontrados em Ratones. Entretanto, o percentual de fósforo inorgânico determinado no manguezal de Itacorubi (84\%) foi maior do que o de Ratones (58\%), possivelmente devido à contaminação urbana. A importância do aporte de esgoto doméstico para o manguezal do Itacorubi foi avaliada a partir da concentração do coprostanol que variou, em média, de $7,7 \mathrm{ng} \mathrm{g}^{-1}$ em Ratones para $1,42 \mu \mathrm{g} \mathrm{g}^{-1}$ no Itacorubi. Esse nível elevado é compatível com valores encontrados em outros ambientes contaminados.
\end{abstract}

Lipid compounds from seven sedimentary stations were used to assess sources of organic matter in two mangrove ecosystems located on Santa Catarina Island, southern Brazil. Ratones Mangrove forms part of a national preservation area and has suffered only minimal human influence. Itacorubi Mangrove has been seriously impacted by anthropogenic activities due to its proximity to the city of Florianopolis. Higher levels of total organic carbon $\left(2.13 \mathrm{mmol} \mathrm{g}^{-1}\right)$ and total phosphorus $\left(14.9 \mu \mathrm{mol} \mathrm{g}^{-1}\right)$ were found in Ratones Mangrove sediments. However, sediments from Itacorubi showed a greater percentage of inorganic phosphorus (84\%) than those from Ratones (58\%), which can be related to urban contamination. The importance of sewage outfalls into the tidal creeks crossing Itacorubi Mangrove was clearly seen as the concentration of coprostanol averaging $7.7 \mathrm{ng}$ $\mathrm{g}^{-1}$ in Ratones sediments was found to be as high as $1.42 \mu \mathrm{g} \mathrm{g}^{-1}$ in Itacorubi, which is comparable to other sewage contaminated hydrosystems.

Keywords: sediments, mangrove, Ratones, Itacorubi, phosphorus, coprostanol

\section{Introduction}

The presence of lipid compounds in sediments has been widely used as a proxy to evaluate possible sources of organic matter. Of particular relevance to estuaries are organic compounds such as ketones, sterols, $n$-alkanols, $n$-alkanes, fatty acids and hydroxy acids. ${ }^{1-3}$ However, it is well known that the correlation to a specific living organism is rather difficult and other biogenic parameters (e.g. C, N, and P) may be used for the assessment of specific source. ${ }^{4-6}$ Mangrove sediments, for instance, are of great complexity due to the tidal influx of allochthonous organic matter and also the input of terrigenous debris from local vegetation. ${ }^{6,7}$ Thus, it is important to employ as many parameters as possible to evaluate the dominant indicators

* e-mail: madureira@qmc.ufsc.br for terrestrial and aquatic inputs. Apart from natural contributions, mangroves are also susceptible to inputs of pollutants from diffuse sources. In most coastal areas, mangroves are an important receptor of such pollutants, from the atmosphere, continental runoff and tidal currents.

Several studies have already emphasized the great importance of the mangroves located on Santa Catarina Island as natural habitats and food sources for many crustaceans, fishes, birds and even reptiles and mammals., Our contribution was to analyze biogenic parameters as well as organic compounds in sediment samples taken from two mangrove ecosystems: Ratones and Itacorubi. Sterols, $n$ alkanes and $n$-alkanols are the principal compound classes that will be addressed in this study. Sterols are widely distributed in living organisms. Potential sources include sewage matter, estuarine phytoplankton and zooplankton as well as terrestrial vascular plants. Some types of sterols 
may also originate from new syntheses within the sediments and from secondary transformation products arising from bioconversion of primary sterols. ${ }^{10} \mathrm{C}_{28}$ and $\mathrm{C}_{29}$ desmethyl sterols in sediments that are believed to originate predominantly from vascular plants include: campesterol (24-methyl-5-cholesten-3 $\beta$-ol), $\beta$-sitosterol (24 $\alpha$-ethyl-5cholesten-3 $\beta$-ol), and stigmasterol ( $24 \alpha$-ethyl-5, (22E)cholestadien-3 $\beta$-ol). ${ }^{11}$ In spite of these compounds being commonly used as tracers of continentally derived organic matter inputs into marine systems, inferences drawn from sterol distributions regarding terrigenous vs. marine sources of organic matter must be made with caution. ${ }^{10,12,13}$ Animals are thought to be unable to synthesize sterols containing an alkyl chain at the C-24 position. ${ }^{14,15}$ However, lower fungal classes are known to synthesize a variety of $\mathrm{C}_{28}$ and $\mathrm{C}_{29}$ sterols. ${ }^{14}$ In contrast to the $\mathrm{C}_{28}-\mathrm{C}_{29}$ sterols, $\mathrm{C}_{27}$ sterols are mainly assigned to planktonic sources, including zooplankton and other aquatic fauna. ${ }^{10}$ Cholesterol (cholest5 -en-3 $\beta$-ol) is the major sterol of crustacea and other zooplankton, and originates from bioassimilation and conversion of dietary phytosterols. ${ }^{14}$ Some phytoplanktons, principally dinoflagellates, also synthesize small quantities of cholesterol directly. ${ }^{16}$ In addition to exogenous input, cholesterol and other $\mathrm{C}_{27}$ sterols in sediments may also be synthesized by some benthic animals, principally polychaetes, echinoderms and bivalves, as well as fungi and some protozoa, ${ }^{15}$ or can be produced as transformation products of $\mathrm{C}_{28}-\mathrm{C}_{29}$ sterols. $\mathrm{C}_{27}$ sterols may also arise from the bioconversion of dietary $\mathrm{C}_{28}$ and $\mathrm{C}_{29}$ sterols, by dealkylation of the sterol side chain at C-24. ${ }^{15}$ Cholesterol is of particular interest, not only because it is the main sterol commonly detected in sediments but also because it can generate another important sterol: coprostanol $(5 \beta$ cholestan-3 $\beta$-ol). Coprostanol and other stanols (ringsaturated sterols) are primarily microbial transformation products of sterols containing $\Delta^{5}$ double bonds, ${ }^{17}$ or of steroidal ketone intermediates. ${ }^{18}$ Stanols are an important component of particulate material. Within sediments, stanols may be produced during sterol degradation by free-living bacteria associated with organic detritus, and by enteric bacteria within the guts of benthic macrofauna. Coprostanol has been considered as a potential indicator of water/ sediment contamination by sewage. ${ }^{19,20}$ Quantitative results for this compound in both mangrove environments will be discussed.

The within-class distributions of long-chain $\left(>\mathrm{C}_{20}\right)$ $n$-alkanes, $n$-alkanoic acids and $n$-alkanols are often used to infer terrestrial input into sediments. ${ }^{21,22}$ These compounds are abundant in plant epicuticular waxes, ${ }^{23}$ but long-chain $n$-alkanes and $n$-alkanoic acids can also be found in marine algae. ${ }^{24-26}$

\section{Materials and Methods}

\section{Study area}

Mangroves are subject to regular or occasional inundation by water of riverine, estuarine, or oceanic origin. Waters inundating mangroves regularly can have a salinity up to $35 \%$ without adversely impacting the function of mangroves, as long as the trees are protected from wave action and strong currents. Mangroves are best developed in tropical climates, where the coldest winter temperature is above $20^{\circ} \mathrm{C}$ and temperatures are fairly constant throughout the year. Soils are generally finegrain, rich in organic matter and periodically waterlogged. Mangroves have salt-tolerant trees that grow most prolifically along low-lying depositional coasts and deltas, where the substrate is predominantly clay and silt rather than sand. This suggests the importance of river-borne nutrients and organic matter in fueling the productivity of mangrove wetlands, since nutrients and organic materials often are adsorbed onto sediment particles. ${ }^{6,27}$

In Santa Catarina State, southern Brazil, mangroves cover $175 \mathrm{~km}$ of the coast representing $17 \%$ of the littoral. ${ }^{28}$ Santa Catarina Island (Figure 1a), where the state capital Florianópolis is located, has five major mangrove areas. Ratones Mangrove is located approximately $30 \mathrm{~km}$ northwest of the city center with a total area of $6.25 \mathrm{~km}^{2}$ (Figure 1b). It is part of Carijós Biological Reserve and has restricted access with no human activities allowed. It presents chemical and biological characteristics which are particularly well preserved, and thus serves as a useful template for comparisons. ${ }^{29}$ In contrast to Ratones Mangrove, Itacorubi Mangrove is surrounded by the city of Florianópolis and has been undergoing progressive loss of habitat for the past 30 years (Figure 1c), with less than $2.0 \mathrm{~km}^{2}$ of mangrove forests left, equivalent to $25 \%$ of its original dimensions. ${ }^{9}$ Part of the mangrove was cut to build a deposit of municipal waste, condominiums and highways. Artificial channels have also been dredged by the municipal government. Sewage treatment is insufficient in the area and untreated wastes are discharged directly into the creeks crossing the mangrove area. ${ }^{8,9}$

\section{Sample collection}

Sediment samples were collected from the bottom $(0-$ $5 \mathrm{~cm}$ depth) of the two major tidal rivers crossing Itacorubi Mangrove, and from two locations along the Ratones River, the main tidal river at Ratones Mangrove, using a van Veen grab sampler. Two samples were also taken from the mud flat flooded area at the margin of Ratones River using 

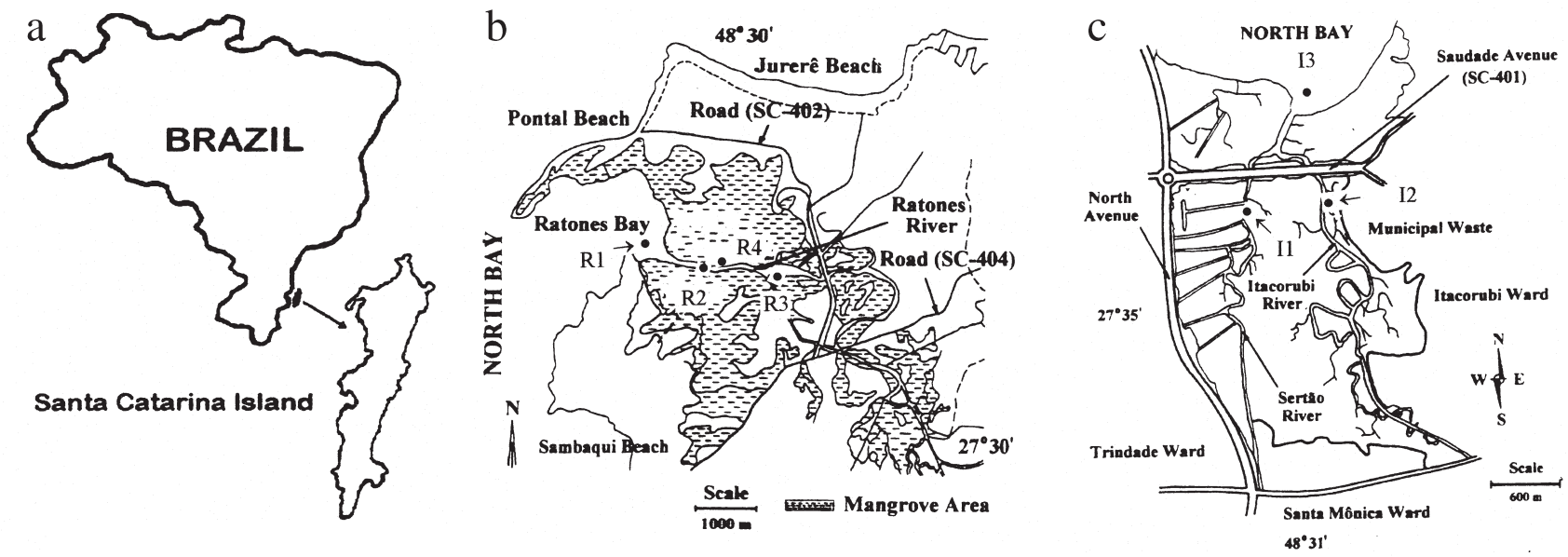

Figure 1. Map of sites for all samples analyzed in this study. (a) Santa Catarina Island localization; (b) Ratones Mangrove. Location of sampling sites along the Ratones River: bottom sediment samples of stations R1 and R2 were taken from the river mouth and upriver, respectively. Samples of stations R3 and R4 were taken from mud flat flooded areas at the margin of the river; (c) Itacorubi Mangrove. Bottom sediment samples were taken from rivers Sertão and Itacorubi, stations I1 and I2, respectively. Station I3 is located at the estuary.

glass jars and a stainless steel spatula. The location of each sampling station is shown in Figures $1 \mathrm{~b}$ and $1 \mathrm{c}$. All samples were immediately immersed in $\mathrm{CH}_{2} \mathrm{Cl}_{2}(2 \mathrm{~mL})$, stored in previously-combusted $\left(450^{\circ} \mathrm{C}\right)$ glass jars, sealed with aluminum foil-lined lids and kept frozen until freezedried in the laboratory.

\section{Bulk parameters}

Immediately prior to lipid extraction, the storage solvent was evaporated and the sediment freeze-dried (Edwards F105) under vacuum and homogenized by griding. Aliquots were taken for elemental analyses. Samples were decarbonated using $0.5 \mathrm{~mol} \mathrm{~L}^{-1} \mathrm{HCl}$ solution. Total organic carbon (TOC) and nitrogen were measured using a Carlo Erba EA1110 CHNS-O analyzer after being centrifuged, washed with deionized water and gently dried at $60{ }^{\circ} \mathrm{C}$.

\section{Particle size distribution}

Sample from all stations were taken for granulometric analyses following the procedure described by Suguio. ${ }^{30}$

\section{Phosphorus analysis}

From each station, two subsamples of $0.1 \mathrm{~g}$ of dried sediment each were used for phosphorus analyses. One subsample was initially placed into a furnace for 1 hour at $500{ }^{\circ} \mathrm{C}$. After that, both subsamples were then shaken with $10 \mathrm{~mL}$ of $1.0 \mathrm{~mol} \mathrm{~L}^{-1} \mathrm{HCl}$ solution $(2 \mathrm{x})$ for $1 \mathrm{~h}$ on a shaker. After centrifugation (6000 rpm, $10 \mathrm{~min})$, the liquid phase was placed in a Teflon ${ }^{\circledR}$ digestor. Phosphorus extracted from the calcinated fraction is considered to be the total phosphorus (TP) and phosphorus extracted from the second treatment, with no calcination, the inorganic phosphorus (IP). Both fractions were digested for $4 \mathrm{~h}$ with $1.6 \mathrm{~mL}$ of potassium persulphate and $4.5 \mathrm{~mol} \mathrm{~L}^{-1}$ sulphuric acid solution at $80^{\circ} \mathrm{C}$. TP and IP fractions were determined as orthophosphate using the acidic molybdate-ascorbic acid method $^{31}$ modified by Koroleff. ${ }^{32}$ The organic fraction (OP) was obtained by the difference TP - IP. Procedural blanks did not reveal any contamination.

In order to evaluate the extraction efficiency of our method for phosphorus analysis (TP), a certified estuarine sediment sample (NIST, SRM1646a) was also analyzed. The result obtained is not significantly different from the TP certified (t-student, $\mathrm{P}<0.05, \mathrm{n}=5$ ).

\section{Analytical procedure}

Lipids were extracted from the remaining freeze-dried samples for analysis. From each station, around $20 \mathrm{~g}$ of sediment were placed in glass tubes. The extractable lipids were obtained by successive extraction of the sediment with a mixture of $\mathrm{CH}_{2} \mathrm{Cl}_{2}: \mathrm{CH}_{3} \mathrm{OH}(2: 1, \mathrm{v} / \mathrm{v}, 1 \mathrm{x})$ and $\mathrm{CH}_{2} \mathrm{Cl}_{2}$ $(2 \mathrm{x})$, by ultra-sound for $20 \mathrm{~min}$ each. A solvent/sediment ratio of approximately 3:1 was used. Extracts were combined and rotary evaporated to just dryness. Lipids were then taken up in $2 \mathrm{~mL}$ of $\mathrm{CH}_{2} \mathrm{Cl}_{2}$ and passed through a Pasteur pipette minicolumn containing $1 \mathrm{~g}$ of combusted $\mathrm{Na}_{2} \mathrm{SO}_{4}$ to remove any residual water. ${ }^{33}$ Lipid isolations were performed in a glass column $(0.5 \mathrm{~cm}$ i.d. x $4 \mathrm{~cm}$ effective length) filled with previously activated alumina 
( $2 \mathrm{~g}$, top part of the column) and silica (2 g, lower part). ${ }^{34}$ The lipid extract was fractionated into three fractions using solvents of increasing polarity: F1 eluted with $18 \mathrm{~mL}$ hexane (hydrocarbons), F2 eluted with $20 \mathrm{~mL} \mathrm{CH}_{2} \mathrm{Cl}_{2}$ (PAHs, aldehydes and ketones) and F3, containing the sterols and $n$-alkanols, eluted with $25 \%$ methanol in ethyl acetate. This latter fraction was treated with urea adduct to separate $n$-alkanols and sterols. Each fraction was transferred to small vials $(2 \mathrm{~mL})$ and stored frozen at $-18^{\circ} \mathrm{C}$ until analysis by gas chromatography (GC) and gas chromatography - mass spectrometry (GC - MS). Immediately before $\mathrm{GC}$ and $\mathrm{GC}-\mathrm{MS}$ analyses, sterols and $n$-alkanols were converted to trimethylsilylether derivatives using bis(trimethylsilyl)-trifluoroacetamide (BSTFA). A known amount of $5 \alpha$-cholestane was added to fractions F1 and F3 (adduct and non-adduct sub-fractions) as an internal standard. Individual compounds were quantified from gas chromatographic peak areas by comparison with the area of the internal standard.

GC analyses were carried out on a model 17A Shimadzu GC fitted with a split/splitless injetor and a flame ionization detector. Temperatures: capillary injection port $300{ }^{\circ} \mathrm{C}$, detector $320{ }^{\circ} \mathrm{C}$. Injection mode: manual $(1 \mu \mathrm{L})$ splitless (inlet purge on for $0.5 \mathrm{~min}$ ) with a split flow 1:40. The column was a DB- 1 capillary column of $30 \mathrm{~m} \times 0.25 \mu \mathrm{m}$ i.d. and $0.25 \mathrm{~mm}$ film thickness, with the following oven temperature program: $50-180{ }^{\circ} \mathrm{C}$ at $10{ }^{\circ} \mathrm{C} \mathrm{min}^{-1}, 150$ $310^{\circ} \mathrm{C}$ at $4{ }^{\circ} \mathrm{C} \mathrm{min}{ }^{-1}$, with a $15 \mathrm{~min}$ isotherm at $310^{\circ} \mathrm{C} . \mathrm{N}_{2}$ was used as the carrier gas.

Data acquisition and processing were performed on a Shimadzu CLASS-GC10 integrator. GC - MS analyses (EI mode, $70 \mathrm{eV}$; mass range 40 - 550 Daltons; $2.0 \mathrm{scan} \mathrm{s}^{-1}$ ) were carried out on a Shimadzu QP2000A MS interfaced to a model 14A Shimadzu GC. Conditions for GC - MS analyses were as for $\mathrm{GC}$ except that $\mathrm{He}$ was used as the carrier gas. Identification of the compounds was based on comparing the gas chromatographic retention times of some peaks with those of authentic standards and by characteristic mass fragmentograms. Structural assignments were achieved by comparison with mass spectra published in the literature.

\section{Results and Discussion}

\section{Elemental composition}

Biogenic parameters and molar ratios for both locations are listed in Table 1. In Ratones Mangrove sediments, TOC values vary by a factor of 5.8 , with maximum content at station R1 $\left(2.13 \mathrm{mmol} \mathrm{g}^{-1} ;<3 \%\right)$, which is the highest value measured in both mangrove environments. Minimum content $\left(0.37 \mathrm{mmol} \mathrm{g}^{-1}\right)$ occurs at station R2. In Itacorubi Mangrove sediments, TOC values do not show a considerable range, remaining between 1.49 and $1.87 \mathrm{mmol} \mathrm{g}^{-1}$. The range of TOC values is consistent with those reported in other mangrove ecosystems and subtropical estuaries. ${ }^{35}$ In Ratones TP ranges from 3.33 to $14.9 \mu \mathrm{mol} \mathrm{g}^{-1}$ and, in Itacorubi, from 3.23 to $4.21 \mu \mathrm{mol} \mathrm{g}^{-1}$. The highest values of TP and TOC were found at the same station (R1). It is possible that the greater difference between maximum and minimum TOC at Ratones occurs because of the distinct locations from where the samples were taken (Figure 1b). Station R1 at the Ratones River mouth is a shoal formed by mud and silt deposition which enhances the accumulation of organic carbon, nitrogen and phosphorus. In contrast, station R2 is nearly $1 \mathrm{~km}$ upriver and is under the influence of the tidal currents of the river, leading to a lower accumulation of organic matter.

Molar TOC/TP ratios range from 111 to 163 in Ratones Mangrove sediments. Stations R2 and R4 (111 and 120, respectively) have values nearer the expected Redfield ratio of 106 for recent marine organic matter whereas higher values are seen for stations R1 and R3 (143 and 163, respectively). ${ }^{36}$ The other two ratios shown in Table 1 also suggest a mix of terrestrial and fresh marine organic matter of close to Redfield proportions for Ratones Mangrove sediments (TOC/N and N/TP averages 9 and 15, respectively). It has been established that $\mathrm{C}: \mathrm{P}$ and $\mathrm{N}: \mathrm{P}$

Table 1. Bulk sediment parameters and molar ratios at the Ratones and Itacorubi mangrove stations

\begin{tabular}{|c|c|c|c|c|c|c|c|c|}
\hline Station & $\begin{array}{c}\text { TOC } \\
\left(\mathrm{mmol} \mathrm{g}^{-1}\right)\end{array}$ & $\begin{array}{c}\mathrm{N} \\
\left(\mathrm{mmol} \mathrm{g}^{-1}\right)\end{array}$ & $\begin{array}{c}\mathrm{TP} \\
\left(\mu \mathrm{mol} \mathrm{g}^{-1}\right)\end{array}$ & $\begin{array}{c}\text { OP } \\
\left(\mu \mathrm{mol} \mathrm{g} \mathrm{g}^{-1}\right)\end{array}$ & $\begin{array}{c}\mathrm{IP} \\
\left(\mu \mathrm{mol} \mathrm{g}^{-1}\right)\end{array}$ & $\begin{array}{l}\text { TOC/TP } \\
\text { (molar) }\end{array}$ & $\begin{array}{r}\mathrm{TOC} / \mathrm{N} \\
\text { (molar) }\end{array}$ & $\begin{array}{c}\text { N/TP } \\
\text { (molar) }\end{array}$ \\
\hline $\mathrm{R} 1$ & 2.13 & 0.26 & 14.90 & 6.12 & 8.78 & 143 & 8 & 17 \\
\hline $\mathrm{R} 2$ & 0.37 & 0.04 & 3.33 & 1.43 & 1.90 & 111 & 9 & 12 \\
\hline R3 & 1.94 & 0.22 & 11.90 & 5.20 & 6.70 & 163 & 9 & 18 \\
\hline R4 & 0.81 & 0.09 & 6.76 & 2.63 & 4.13 & 120 & 9 & 13 \\
\hline I 1 & 1.87 & 0.24 & 3.23 & 0.67 & 2.56 & 444 & 8 & 57 \\
\hline $\mathrm{I} 2$ & 1.49 & 0.23 & 4.21 & 0.54 & 3.67 & 461 & 6 & 71 \\
\hline I3 & 1.64 & 0.22 & 4.16 & 0.53 & 3.63 & 394 & 7 & 53 \\
\hline
\end{tabular}

Ratones: R1, R2, R3, and R4. Itacorubi: I1, I2, and I3; Phosphorus: Total (TP), inorganic (IP) and organic (OP); TOC: total organic carbon; Values shown are the average of three replicate analyses. RSD $<3.8 \%$. 
values in freshwater generally tend to be higher than in the marine environment, so it is possible that the mangrovederived organic matter brought by the river flux to the shoal areas during the ebb tide is responsible for the higher TOC/TP and N/TP values found at R1 and R3 stations. ${ }^{6}$

In contrast to Ratones Mangrove, the sediments from Itacorubi have a TOC/TP average ratio approximately 3.2 times higher than that for the sediments from Ratones. High TOC/TP values in Itacorubi Mangrove indicate that the sediments from the rivers Itacorubi and Sertão are either very poor in sedimentary $\mathrm{P}$ or extremely rich in organic carbon. By looking at $\mathrm{TOC} / \mathrm{N}$ ratios in Table 1 , it is possible to note that the values are in agreement with the Redfield ratio, but N/TP values of $57-71$ are very high, suggesting that the sediments are relatively depleted of $\mathrm{P}$ in relation to $\mathrm{N}$ and TOC. In fact, an increase in C/TP and N/TP ratios in sediments is probably due to a higher productivity in the water column, in response to an increased anthropogenic input of nitrate and phosphate. ${ }^{37}$ Nonetheless, it is also important to mention that as both mangrove systems receive high terrestrial and marine inputs strong diagenetic effects occur in the sediments being responsible for the main changes in the Redfield ratio.

In Ratones Mangrove the particle size distribution revealed that the sample from station R2 taken from the bottom of Ratones River, has the highest sand content (78\%), which drops to less than $10 \%$ for samples from stations R3 and R1, which were taken from the margin of the river and from the river mouth, a shoal area, respectively (Figure 2a). Station R4 was also sampled from the margin of the river, but is dominated by sand (68\%). TOC has a strong negative correlation to sand content $(\mathrm{r}=-0.988, \mathrm{P}<0.05, \mathrm{n}=3)$, having maximal values at stations R3 and R1, which are nearly 3.5 times higher than those at the two other stations (R2 and R4). Silt and clay are the dominant sedimentary components at stations R3 and R1 (> 90\%). Such high percentages of fine particles are commonly found along with high TOC levels, ${ }^{38,39}$ which suggest that these may be areas of major accumulation of continental detritus.

Particle fractions do not vary considerably in the sediments of Itacorubi Mangrove (Figure 2b), probably because all samples were taken from the bottom of rivers. The sediments are composed mainly of silt $(59-69 \%)$ with a very low percentage of clay $(<12 \%)$. As in Ratones Mangrove sediments, the increase in TOC content was also associated with decrease in sand percentage. But this relationship is not as pronounced as that of the sediments from Ratones as TOC values vary very little among the sediments in Itacorubi Mangrove $\left(1.49-1.87 \mathrm{mmol} \mathrm{g}^{-1}\right)$.
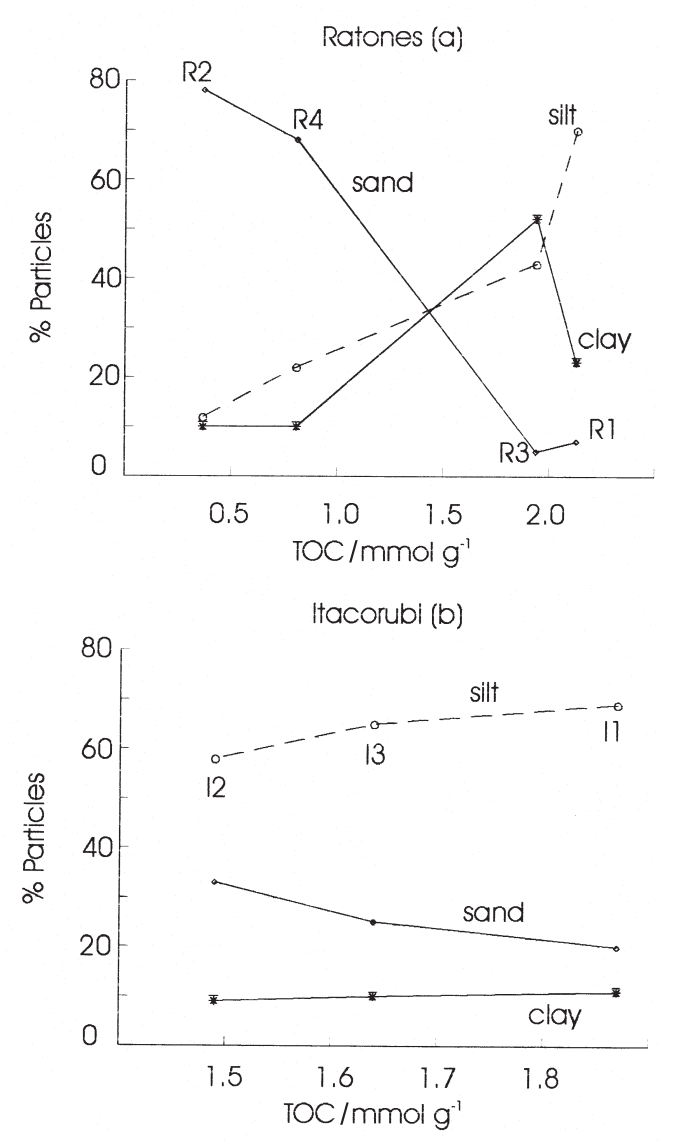

Figure 2. Correlation between particle size (\%) x TOC in sediments of Ratones (a) and Itacorubi (b) mangroves.

Interesting results were seen for the $\mathrm{P}$ fractions (Figures $3 \mathrm{a}$ and $3 \mathrm{~b}$ ). In the sediments of Ratones, samples contain an average of $58 \%$ IP, ranging from $59 \%$ to $61 \%$. However, IP content is quite high in Itacorubi Mangrove, making up nearly $84 \%$ of TP $(79-87 \%)$. These results indicate that the proportion of OP:IP seems to be affected by sources of phosphorus. High content of IP was suggested by Brunskill et al. ${ }^{35}$ as being accountable for the major fraction of total phosphorus in the open water sediments of Exmouth Gulf. However, the proportions of TOC:P and N:TP were far below Redfield ratios and they assumed that the organic carbon and nitrogen could be rapidly oxidized in the water column and surface sediments. Previous works have shown that IP is usually accountable for $60 \%$ of TP in sediments without anthropogenic input. Such results agree with phosphorus content found in the sediments of Ratones Mangrove and may explain why the IP:TP is so high in the Itacoburi sediments.

Brunskill et al., ${ }^{35}$ working with sediments from Exmouth Gulf, reported that sedimentary TOC/TP and N/ TP ratios did not show useful relationships with the abundance of fine particles. In terms of ratios, these results 


\section{Ratones (a)}

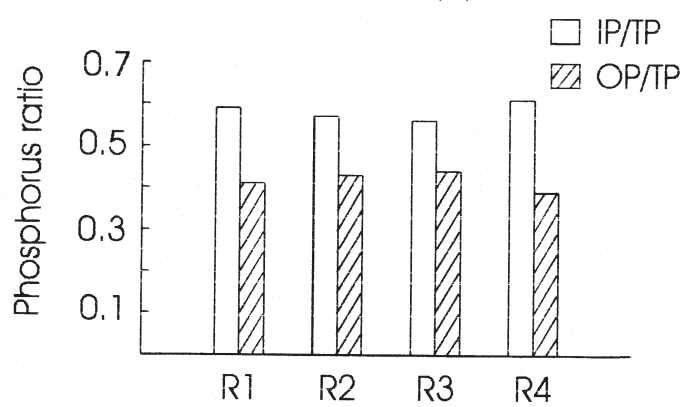

Itacorubi (b)

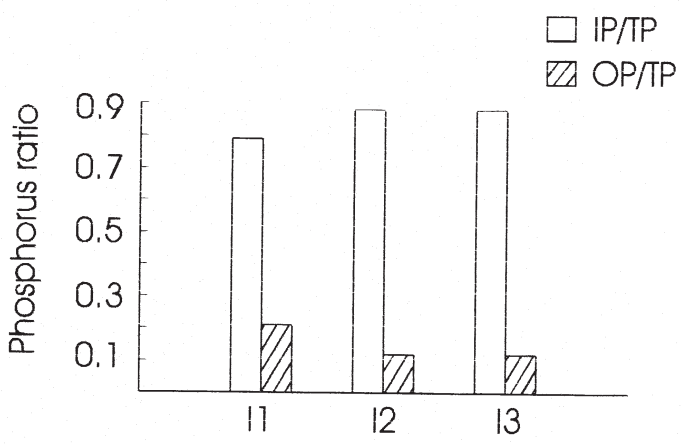

Figure 3. Histograms of IP/TP and OP/TP ratios in sediments of Ratones (a) and Itacorubi (b) mangroves.

agreed in part with what was seen for both mangroves. In our work, the correlation matrix calculated from the biological and particle size data showed that several parameters are significantly correlated (Table 2). Both mangrove sediments show very high correlations between TOC and TP $(r>0.800)$. In Ratones, TOC also correlates with $\mathrm{N}(\mathrm{r}=0.998, \mathrm{P}<0.05, \mathrm{n}=3)$, but to a lesser extent in
Itacorubi ( $\mathrm{r}=0.601)$. Apart from TOC, $\mathrm{N}$ and $\mathrm{TP}$, other parameters are also well correlated. For instance, silt and clay show good correlation with OP at both locations $(r>0.650)$. In Ratones sand is negatively correlated with all other parameters, whereas in Itacorubi it shows a positive correlation with IP only ( $\mathrm{r}=0.811, \mathrm{P}<0.05, \mathrm{n}=3$ ). TP is significantly correlated with IP and OP in Ratones $(r>0.99)$, but it has non-significant correlation with OP and a negative correlation with IP ( $\mathrm{r}=-0.565)$ in Itacorubi. Other interesting results were the strong correlation between silt and IP in Ratones ( $r=0.979, \mathrm{P}<0.05, \mathrm{n}=3)$ and the negative correlation between them in Itacorubi $(r=-0.797)$. $\mathrm{N}$ has no correlation with TP in Itacorubi, but these parameters correlate nicely to each other in Ratones $(\mathrm{r}=0.993, \mathrm{P}<0.05, \mathrm{n}=3)$. From the matrix correlations shown in Table 2 we can conclude that the major difference between both mangroves occurs mainly due the $\mathrm{P}$ composition.

\section{Lipid compounds}

Here we will discuss data on $n$-alkane, $n$-alkanol and sterol concentrations and distribution patterns of individual compounds in sediments from both mangroves (Table 3). For all samples, the distribution of total $n$-alkanes $\left(\mathrm{C}_{20}\right.$ $\mathrm{C}_{36}$ ) shows an odd carbon number predominance with major contributions ranging from $\mathrm{C}_{25}$ to $\mathrm{C}_{33}$. Concentrations are higher at station $\mathrm{R} 1\left(10.1 \mu \mathrm{g} \mathrm{g}^{-1}\right.$ dry sediment) than at other stations of Ratones Mangrove. Station R2 has a very low value, nearly 55 times lower than that of station R1. Such strong variation is not observed in the Itacorubi sediments, and values have the same order of magnitude at all stations $\left(4.2-6.3 \mu \mathrm{g} \mathrm{g}^{-1}\right)$. With respect to total $n$-alkanols $\left(\mathrm{C}_{15}-\mathrm{C}_{34}\right)$,

Table 2. Correlation coefficients (r) calculated for all biogenic and granulometric parameters in Ratones and Itacorubi mangrove sediments

\begin{tabular}{|c|c|c|c|c|c|c|c|c|}
\hline Ratones & TOC & Sand & Silt & Clay & $\mathrm{N}$ & $\mathrm{TP}$ & IP & OP \\
\hline TOC & 1.000 & & & & & & & \\
\hline Sand & -0.988 & 1.000 & & & & & & \\
\hline Silt & 0.938 & -0.891 & 1.000 & & & & & \\
\hline Clay & 0.726 & -0.810 & 0.456 & 1.000 & & & & \\
\hline $\mathrm{N}$ & 0.998 & -0.980 & 0.959 & 0.683 & 1.000 & & & \\
\hline $\mathrm{TP}$ & 0.987 & -0.951 & 0.974 & 0.606 & 0.993 & 1.000 & & \\
\hline IP & 0.975 & -0.930 & 0.979 & 0.560 & 0.984 & 0.998 & 1.000 & \\
\hline $\mathrm{OP}$ & 0.996 & -0.974 & 0.962 & 0.666 & 0.999 & 0.996 & 0.989 & 1.000 \\
\hline Itacorubi & TOC & Sand & Silt & Clay & $\mathrm{N}$ & $\mathrm{TP}$ & IP & OP \\
\hline TOC & 1.000 & & & & & & & \\
\hline Sand & -0.968 & 1.000 & & & & & & \\
\hline Silt & 0.962 & -1.000 & 1.000 & & & & & \\
\hline Clay & 0.993 & -0.991 & 0.988 & 1.000 & & & & \\
\hline $\mathrm{N}$ & 0.601 & -0.381 & 0.359 & 0.500 & 1.000 & & & \\
\hline TP & 0.826 & -0.941 & 0.949 & 0.888 & 0.045 & 1.000 & & \\
\hline IP & -0.932 & 0.811 & -0.797 & -0.881 & -0.850 & -0.565 & 1.000 & \\
\hline $\mathrm{OP}$ & 0.893 & -0.752 & 0.736 & 0.832 & 0.896 & 0.484 & -0.995 & 1.000 \\
\hline
\end{tabular}


Table 3. Concentrations of individual (in $\mathrm{ng} \mathrm{g}^{-1}$ ) and total (in $\mu \mathrm{g} \mathrm{g}^{-1}$ ) sterols, $n$-alkanols from $\mathrm{C}_{15}$ to $\mathrm{C}_{34}$, and $n$-alkanes from $\mathrm{C}_{20}$ to $\mathrm{C}_{36}$ in sediments of Itacorubi and Ratones mangroves; CPI: Carbon Preference Index calculated in the $\mathrm{C}_{22}-\mathrm{C}_{32} n$-alkane range. Values shown are the average of duplicate analyses

\begin{tabular}{|c|c|c|c|c|c|c|c|}
\hline Compounds & $\begin{array}{c}\text { Stations } \\
\text { R1 }\end{array}$ & $\mathrm{R} 2$ & $\mathrm{R} 3$ & R4 & I1 & $\mathrm{I} 2$ & $\mathrm{I} 3$ \\
\hline $5 \beta$-Cholestan- $3 \beta$-ol & 11 & 4 & n.d. ${ }^{a}$ & n.d & 896 & 2876 & 485 \\
\hline Cholesta-5,22-dien-3 $\beta$-ol & 39 & n.d. & n.d & n.d & 52 & 86 & 55 \\
\hline Cholest-5-en- $3 \beta$-ol & 215 & 69 & 41 & 90 & 450 & 1076 & 306 \\
\hline $5 \alpha$-Cholestan- $3 \beta$-ol & 287 & 53 & 53 & 21 & 283 & 648 & 278 \\
\hline 24-Methylcholesta-5,22-dien-3 $\beta$-ol & 167 & 61 & 20 & 3 & 152 & 165 & 130 \\
\hline 24-Methylcholest-5-en-3 $\beta$-ol b & 130 & 47 & 16 & 7 & 446 & 973 & 474 \\
\hline 24-Methyl-5 $\alpha$-cholestan- $3 \beta$-ol & 24 & 15 & 3 & 7 & 51 & 121 & 46 \\
\hline 24 -Ethylcholesta-5,22-dien- $3 \beta$-ol & 512 & 111 & 63 & 3 & 178 & 333 & 357 \\
\hline 24-Ethylcholest-5-en-3 $\beta$-ol & 977 & 161 & 184 & 163 & 375 & 742 & 571 \\
\hline 24 -Ethyl- $5 \alpha$-cholestan- $3 \beta$-ol & 534 & 88 & 66 & 13 & 225 & 556 & 506 \\
\hline Total sterols & 2.9 & 0.6 & 0.5 & 0.3 & 3.1 & 7.6 & 3.2 \\
\hline Total $n$-alkanols $\left(\mathrm{C}_{15}-\mathrm{C}_{34}\right)$ & 1.5 & 0.2 & 0.3 & 0.7 & 1.8 & 1.8 & 0.6 \\
\hline Total $n$-alkanes $\left(\mathrm{C}_{20}-\mathrm{C}_{36}\right)$ & 10.1 & 0.2 & 1.9 & 3.3 & 4.2 & 6.3 & 5.4 \\
\hline $\mathrm{CPI}\left(\mathrm{C}_{22}-\mathrm{C}_{32}\right)(n$-alkanes $)$ & 6.3 & 3.1 & 7.1 & 6.9 & 3.4 & 3.5 & 3.5 \\
\hline
\end{tabular}

${ }^{a}$ n.d. - not detected; ${ }^{b}$ There is a coelution with $24-$ Ethyl- $5 \beta$-cholestan- $3 \beta$-ol in the sediments of Itacorubi.

samples from both mangroves show predominance of compounds with even carbon numbers, mainly those extending from $\mathrm{C}_{24}$ to $\mathrm{C}_{28}$. In the sediments of Ratones, higher concentration of total $n$-alkanols is also detected at station $\mathrm{R} 1\left(1.5 \mu \mathrm{g} \mathrm{g}^{-1}\right)$ and the lowest value is registered at station $\mathrm{R} 2\left(0.2 \mu \mathrm{g} \mathrm{g}^{-1}\right)$. Two stations at Itacorubi mangrove have concentrations of total $n$-alkanols higher than those for the sediments of Ratones (stations I1 and I2: $1.8 \mu \mathrm{g} \mathrm{g}^{-1}$ ). As reported by other authors, ${ }^{39-41}$ the distribution of $n$-alkanes and $n$-alkanols seen in both mangrove ecosystems are commonly attributed to land plant inputs.

Carbon Preference Index (CPI) values were calculated in the range of the $\mathrm{C}_{22}-\mathrm{C}_{32} n$-alkanes for both mangroves (Table 3). The results show that CPI values for the sediments from Ratones are higher than 6 , with the exception of station R2 (3.1). This low value suggests that sediments at this part of Ratones River receive a very low contribution of terrigenous particulate material. In fact, this result is consistent with the low abundance of total long-chain $n$ alkanes found at this station (Table 3). In contrast to the high values found at Ratones stations, CPI values in the sediments of Itacorubi Mangrove are much lower (averaging 3.5). As for station R2, these values can also be interpreted as reflecting a higher autochthonous character of the samples indicating that Itacorubi sediments have a predominant aquatic input. However, it is interesting to note that the abundance of long-chain $n$-alkanes in Itacorubi is not as low as that at station R2 (Table 3). The CPI results from both mangroves suggest that despite the great abundance of $n$-alkanes found at almost all stations, it is clear that they have relatively distinct autochthonous and allochthonous inputs.
With regard to total sterols, again station $\mathrm{R} 1$ has the highest value $\left(2.9 \mu \mathrm{g} \mathrm{g}^{-1}\right)$ nearly 9.4 times that for station $\mathrm{R} 4\left(0.3 \mu \mathrm{g} \mathrm{g}^{-1}\right.$; Table 3$)$. The value found at station $\mathrm{R} 1$ is similar to those from other areas rich in biogenic input such as the Yangtze estuary and the outer estuary of the Mackenzie River $\left(\sim 1.0-3.3 \mu \mathrm{g} \mathrm{g}^{-1}\right){ }^{42,43}$ However, these values are lower than those found in superficial sediments of the urban Capibaribe River (average $7.6 \mu \mathrm{g} \mathrm{g}^{-1}$ ), ${ }^{18}$ the Laurentian Trough $\left(\sim 20,000 \mu \mathrm{g} \mathrm{g}^{-1}\right)^{44}$ and the seasonal values obtained in Cape Lookout Bight. ${ }^{1}$ Station R1 can be considered free of fecal sterols and the high concentration of sterols is reflecting inputs from allochthonous and autochthonous sources. Sterols in Ratones Mangrove sediments are dominated by 24 -ethylcholest-5-en- $3 \beta$-ol $\left(\mathrm{C}_{29} \Delta^{5}\right)$ followed by other $\mathrm{C}_{29}$ sterols. These sterols are usually associated with higher plant inputs but they can be also attributed to marine sources. ${ }^{13}$ In contrast to Ratones, sterols in the sediments of Itacorubi were dominated by $5 \beta$-cholestan$3 \beta$-ol (coprostanol), which is generally employed as a fecal pollution indicator. ${ }^{45}$ However, it is important to mention that some authors have already emphasized that coprostanol can be found in algae ${ }^{45,46}$ and also the reduction of $\Delta^{5}$ sterols in sediments usually produces stanol mixtures where $5 \alpha$ epimers are dominant. ${ }^{19}$ Nonetheless, using the $(5 \beta / 5 \beta+$ $5 \alpha$ ) stanol ratio proposed by Grimalt et al. ${ }^{45}$ for sewage pollution identification, we found ratios ranging from 0.64 to 0.82 for the sediments of Itacorubi and very low values for Ratones, from 0.04 to 0.07 (Table 4). Values of this ratio higher than 0.70 are considered to be indicative of significant sewage contamination. ${ }^{20,45}$

As cholest-5-en-3 $\beta$-ol and 24 -ethylcholest-5-en-3 $\beta$-ol have been shown to relate to autochthonous and 
Table 4. Ratios of the isomeric $5 \alpha$ and $5 \beta(\mathrm{H})$-cholestan-3 $\beta$-ols, cholesterol to 24-ethylcholesterol and individual $5 \alpha(\mathrm{H})$-stanols to their $\Delta^{5}$ stenol counterparts determined in the sediments of Ratones and Itacorubi mangroves

\begin{tabular}{lccccccc}
\hline Ratios & Stations & & & & & & \\
& R1 & R2 & R3 & R4 & I1 & I2 & I3 \\
\hline Stanols $(5 \beta / 5 \beta+5 \alpha)$ & 0.04 & 0.07 & $-^{\text {a }}$ & - a & 0.76 & 0.82 & 0.64 \\
Cholesterol / Ethylcholesterol & 0.22 & 0.43 & 0.22 & 0.55 & 1.20 & 1.45 & 0.53 \\
Cholestanol / Cholesterol & 1.33 & 0.76 & 1.29 & 0.23 & 0.63 & 0.60 & 0.91 \\
24-Ethylcholestanol / 24-Ethylcholesterol & 0.55 & 0.55 & 0.36 & 0.08 & 0.60 & 0.75 & 0.89 \\
\hline
\end{tabular}

a $5 \beta$-Cholestan- $3 \beta$-ol was not detected.

allochthonous material, respectively, we used the ratio cholesterol/24-ethylcholesterol to evaluate possible changes in marine-terrestrial source inputs and also to compare with data reported by other authors (Table 4). ${ }^{47,48}$ Values of this ratio are higher at stations I1 and I2 (1.20 and 1.45 respectively) in the sediments of Itacorubi Mangrove and are less than 1.0 at other stations in both estuaries $(0.22$ - 0.53). Of note is that stations I1 and I2 are located in Sertão and Itacorubi Rivers, which receive waste discharges containing sewage matter. Compared to stations I1 and I2, it is possible that the lowest value for cholesterol/24ethylcholesterol at station I3 is because of its location, thus also receiving input from marine sources. Considering the possible sewage origin of cholesterol, the high ratio values encountered at Itacorubi stations suggest that no unique source exists for cholesterol and inputs may vary with time from sources such as plankton production, bioaccumulation or domestic discharges. According to Sicre et $a l^{48}$ a low cholesterol/24-ethylcholesterol ratio $(<2.5)$ can be associated with higher allochthonous input. However, it is worth mentioning that their results related to suspended particles, collected from the Chang Jiang Estuary, and not for sediments. Our values were well below 2.5 , but there is a clear indication of anthropogenic contribution for cholesterol. We decided also to calculate this ratio for sediment samples using values available in the literature. The ratio ranged from 0.76 to 1.30 in the sediments of Cape Lookout Bight ${ }^{1}$ and from 1.10 to 4.54 in sediments of the urban Capibaribe River estuary. ${ }^{19}$ In spite of such a wide variation in the cholesterol/24-ethylcholesterol ratio, both studies suggested that these compounds may be mainly derived from autochthonous input.

We also used another ratio that is commonly employed to infer terrestrial contribution for sediments. The relative abundance of three sterols has been found in surface sediments of Loch Clair to be close to 1:1.6:6.6 (24methylcholes-5-en-3 $\beta$-ol:24-ethylcholesta-5,22-dien-3 $\beta$ ol:24-ethylcholest-5-en-3 $\beta$-ol). ${ }^{49}$ The average values for this ratio in the Ratones and Itacorubi sediments were 1:2.6:11.3 and 2.2:1:2, respectively. The sterol 24- ethylcholest-5-en-3 $\beta$-ol largely predominates over the two other sterols in the sediments of Ratones whereas Itacorubi shows a slightly high relative abundance of 24methylcholes-5-en-3 $\beta$-ol. These results indicate that the relative contribution of different sources of organic matter vary between locations. The dominance of 24-ethylcholest5 -en-3 $\beta$-ol suggests a higher vascular land plant input of these compounds to the sediments of Ratones than to Itacorubi. In contrast, the main source of the three sterols seems to be of phytoplanktonic origin in the Itacorubi sediments.

Another interesting issue regarding sterols is the possible changes that occur on the sterol skeletons. These changes have been used to assess microbially-mediated diagenetic transformation reactions. Two reactions are usually employed, the reduction of cholest-5-en-3 $\beta$-ol to $5 \alpha$-cholestan-3 $\beta$-ol and of 24 -ethylcholest-5-en- $3 \beta$-ol to 24 -ethyl-5 $\alpha$-cholestan- $3 \beta$-ol. ${ }^{50,51}$ However, possible mixtures of $5 \alpha$-stanols from marine organisms cannot be ruled out. Ratios for the two sterol pairs were calculated: $5 \alpha$-cholestan-3 $\beta$-ol/cholest-5-en-3 $\beta$-ol and 24 -ethyl- $5 \alpha$ cholestan-3 $\beta$-ol/24-ethylcholest-5-en-3 $\beta$-ol (Table 4 ). Values for these ratios are higher at stations R1 and R3 of Ratones Mangrove than at any other sites. In general, the results obtained here for both estuaries are very high compared to other studies in which the average values for stanol/stenol pairs are below $0.60 .{ }^{19,48}$ One possible reason for the higher $5 \alpha$-cholestan- $3 \beta$-ol/cholest-5-en- $3 \beta$-ol ratio seen at Ratones stations would be a direct input of $5 \alpha(\mathrm{H})$ stanols from diatoms as they are likely to be found in the estuary. ${ }^{9}$ However, it should be noted that the lowest value found at station R4 (0.23) is consistent with its location, where inputs of marine organisms should be minimal. Furthermore, $5 \alpha$-cholestan- $3 \beta$-ol/cholest-5-en- $3 \beta$-ol and 24 -ethyl-5 $\alpha$-cholestan- $3 \beta$-ol/24-ethylcholest-5-en-3 $\beta$-ol ratios appear to vary independently in the sediments of Ratones Mangrove. On the other hand, the high values found in the sediments of Itacorubi Mangrove indicate that both stanol/stenol ratios are equally affected by the reducing conditions. 


\section{Conclusions}

Our study on the concentration levels of sterols, $n$-alkanols, $n$-alkanes and biogenic elements in the sediments of Ratones and Itacorubi mangroves shows that the distribution and abundance of lipid compounds and C:N:P ratios can be closely related to natural sources of organic matter and also give clear insights of sewage discharges. Biogenic and granulometric parameters showed significant correlation in the sediments of Ratones Mangrove, even for those samples taken from the tidal flat mud at margin of the Ratones River. In contrast, sediments from Itacorubi Mangrove showed non-significant correlation between C, $\mathrm{N}$ and $\mathrm{P}$ values and granulometric fractions. Of note is the negative correlation between IP and the fine particles. This result implies that the abundance of IP in these sediments is severely affected by the sewage discharged into the two rivers crossing the Itacorubi Mangrove. Nitrogen is also affected but not to the same degree.

Quantitative results of characteristic sterols found at station R1 were consistent with biogenic and granulometric correlations. High concentration of coprostanol and the values obtained from the $(5 \beta / 5 \beta+5 \alpha)$ epimeric ratio showed that the sediments of Itacorubi Mangrove are heavily impacted by human activities. As a final comment, from the observation of elemental parameters and particle size correlation, we can state that sewage outfall interferes in the natural intake and uptake balance of phosphorus, nitrogen and organic carbon at the bottom sediment-water interface in both rivers of Itacorubi Mangrove.

\section{Acknowledgements}

Thanks are due to the Rescue \& Save Brigade of Florianópolis City for helping us to collect samples at Itacorubi Mangrove. Dr. Sérgio Antônio Netto and Mr. José Carlos Simonassi for their help with the field work at Ratones Mangrove. Scholarships for Luciana Mater, Marcelo da Rosa Alexandre and Fabrício Augusto Hansel were provided by the Brazilian National Research Council and CAPES. Financial support was provided by Funpesquisa-1997, UFSC.

\section{References}

1. Canuel, E.A.; Martens, S.C.; Deep Sea Res. 1993, 36, 121.

2. Sicre, M-A.; Tian, R.C.; Saliot, A.; Org. Geochem. 1994, 21, 1.

3. Hernandez, M. E.; Mead, R.; Peralba, M. C.; Jaffé, R.; Org. Geochem. 2001, 32, 21.

4. Xu, S.; Gao, X.; Liu, M.; Chen, Z.; Geomorph. 2001, 41, 207.
5. Ruiz-Fernandéz, A. C.; Hillaire-Marcel, C.; Ghaleb, B.; SotoJiménez, M.; Paez-Osuna, F.; Environ. Pollut. 2002, 118, 365.

6. Bouillon, S.; Dahdouh-Guebas, F.; Rao, A. V. V. S.; Koedam, N.; Dehairs, F.; Hydrobiol. 2003, 495, 33.

7. Koch, B. P.; Rullkötter, J.; Lara, R. J.; Wet. Ecol. Manag. 2003, 11, 257.

8. Silva, A. D.; MSc. Dissertation, Universidade Federal de Santa Catarina, Brazil, 1990.

9. Soriano-Sierra, E. J.; Silva, J. R. B. M.; Derner, R. B.; Branco, J. O. In Ecology and Managment of Itacorubi Mangrove; Soriano-Sierra, E. J.; Ledo, B. S., eds., IOESC: Florianópolis, 1998, p. 115.

10. Volkman, J. K.; Org. Geochem. 1986, 9, 83.

11. Heftmann, E.; Lipids 1971, 6, 128.

12. Laureillard, J.; Saliot, A.; Mar. Chem. 1993, 43, 247.

13. Volkman, J. K.; Barret, S. M.; Blackburn, S. I.; Mansour, M. P.; Sikes, E. L.; Gelin, F.; Org. Geochem. 1998, 29, 1163.

14. Goad, L. J. In Marine Natural Products: Chemical and Biological Perpectives. II; Scheuer, P. J., ed., Academic Press: New York, 1987, p. 75.

15. Ikekawa, N. In Sterols and Bile Acids; Danielsson, H.; Sjovall, J., eds., Elsevier: Amsterdam, 1985, p. 180.

16. Bradshaw, S. A.; PhD. Thesis, University of Bristol, UK, 1988.

17. Mermoud, F.; Wunsche, L.; Clerc, O.; Gulacar, F.O.; Buchs, A.; Org Geochem. 1984, 6, 25.

18. Gagosian, R. B.; Smith, S. O.; Lee, C.; Farrington, J. W.; Frew, N. M. In Advances in Organic Geochemistry 1979; Douglas, A. G.; Maxwell, J. R., eds., Pergamon Press: Oxford, 1980, p. 407.

19. Fernandes, M. B.; Sicre, M- A.; Cardoso, J. N.; Macedo, S. J.; Sci. Total Environ. 1999, 23, 1.

20. Carrera, R.; Wagener, A. L. R.; Fileman, T.; Readman, J. W.; Quim. Nova 2001, 24, 27.

21. Rieley, G.; Collier, R. J.; Jones, D. M.; Eglinton, G.; Org. Geochem. 1992, 17, 901.

22. Madureira, L. A. S.; van Kreveld, S. A. V.; Eglinton, G.; Conte, M. H.; Ganssen, G.; Hinte, J. E.; Ottens, J.; Paleocean. 1997, $12,255$.

23. Eglinton, G.; Hamilton, R. J.; Raphael, R. A.; Gonzales, A. G.; Nature 1962, 193, 739 .

24. Volkman, J. K.; Eglinton, G.; Corner, E. D. S.; Phytochem. 1980, 19, 1809.

25. Saliot, A. In Marine Organic Geochemistry; Duursma, E.; Dawson, R., eds., Elsevier: Amsterdam, 1981, p. 237.

26. Venkatesan, M. I.; Kaplan, I. R.; Geochim. Cosmochim. Acta 1987, 46, 2135.

27. Lacerda, 1. D. In Mangrove Ecosystems Occasional Papers No. 2; Vannucci, M, ed., ISME: Okinawa, 1998, p. 65.

28. Ledo, S. B.; Soriano-Sierra, E. J.; Proceedings $4^{\text {th }}$ Symposium on Coastal and Ocean Management "Coastal zone 85”, ASCE, Baltimore, 1985, p. 1170. 
29. De Souza Sierra, M. M.; Giovanela, M.; Soriano-Sierra, E. J.; Environ. Technol. 2000, 21, 979.

30. Suguio, K.; Introdução à Sedimentologia, Universidade de São Paulo: São Paulo, 1973.

31. Murphy, I.; Riley, S. P.; Analyt. Chim. Acta 1962, 27, 223.

32. Koroleff, F. In Methods of Seawater Analysis; $2^{\text {nd }}$ ed., Grasshoff, K.; Ehrhardt, M.; Kremling, K., eds., Verlag Chemie: Weinheim, 1983, 125.

33. Madureira, L. A. S.; Eglinton, G.; Conte, M. H.; Paleoacean. 1995, 10, 627.

34. Wang, Z.; Fingas, M.; Li, K.; J. Chrom. Sci. 1994, 32, 361.

35. Brunskill, G. J.; Orpin, A. R.; Zagorskis, I.; Woolfe, K. J.; Ellison, J.; Continental Shelf Res. 2001, 21, 157.

36. Takahashi, T.; Broecker, W. S.; Langer, S.; J. Geoph. Res. 1985, 90, 6907.

37. Emeis, K. C.; Struck, U.; leipe, T.; Pollehme, F.; Kunzendorf, H.; Christiansen, C.; Mar. Geol. 2000, 167, 43.

38. Muniz, P.; Danulat, E.; Yannicelli, B.; Garcia-Alonso, J.; Medina, G.; Bícego, M. C.; Environ. Int. 2003, 1096, 1.

39. Nishigima, F. N.; Weber, R. R.; Bícego, M. C.; Mar. Pollut. Bull. 2001, 42,1064.

40. Gomes, A. O.; Azevedo, D. A.; J. Braz. Chem. Soc. 2003, 14, 358.
41. Azevedo, D. A.; J. Braz. Chem. Soc. 2003, 14, 97.

42. Tian, R. C.; Sicre, M-A.; Saliot, A.; Org. Geochem. 1992, 18 , 843.

43. Yunker, M. B.; Macdonald, R. W.; Veltkamp, D. J.; Cretney, W. J.; Mar. Chem. 1995, 49, 1.

44. Colombo, J. C.; Silverberg, N.; Gearing, J. N.; Org. Geochem. 1997, 26, 257.

45. Grimalt, J. O.; Fernández, P.; Bayona, J. M.; Albaigés, J.; Environ. Sci. Technol. 1990, 24, 357.

46. Colombo, J. C.; Silverberg, N.; Gearing, J. N.; Org. Geochem. 1996, 25, 211

47. Huang, W-Y.; Meinschein, W. G.; Geochim. Cosmochim. Acta 1976, 40, 323

48. Sicre, M-A.; Tian, R. C.; Broyelle, I.; Saliot, A.; Mar. Chem. 1993, 42, 11.

49. Cranwell, P. A.; Volkaman, J. K.; Chem. Geol. 1981, 32, 29.

50. Gaskell, S. J.; Eglinton, G.; Nature 1975, 254, 209.

51. Nishinura, M.; Koyama, T.; Geochim. Cosmochim. Acta 1977, 41,379 .

Received: October 28, 2003 Published on the web: September 16, 2004 